九州大学学術情報リポジトリ

Kyushu University Institutional Repository

A Systematic Study of the Subgenus Seladonia of the Genus Halictus in Asia (Hymenoptera, Apoidea, Halictidae) II

Dawut, Ahmatjan

Tadauchi, Osamu

https://doi.org/10.5109/2655

出版情報: ESAKIA. 41，pp.161-180，2001-03-31. Entomological Laboratory，Faculty of Agriculture, Kyushu University バージョン：

権利関係 : 


\title{
A Systematic Study of the Subgenus Seladonia of the Genus Halictus in Asia (Hymenoptera, Apoidea, Halictidae) II
}

\author{
Ahmatjan DAWUT \\ Entomological Laboratory, Graduate School of Bioresource and Bioenvironmental Science, \\ Kyushu University, Fukuoka, 812-8581 Japan \\ and \\ Osamu TADAUCHI \\ Entomological Laboratory, Faculty of Agriculture, \\ Kyushu University, Fukuoka, 812-8581 Japan
}

\begin{abstract}
The second report of a systematic study of the subgenus Seladonia Robertson of the genus Halictus (Hymenoptera, Apoidea, Halictidae) in Asia is presented. In the present paper five species, Halictus (Seladonia) seladonius (Fabricius), H. propinquus Smith, H. subauratus (Rossi), H. subauratoides Blüthgen, and $H$. vicinus Vachal are treated.

Key words: taxonomy, Hymenoptera, Halictidae, Halictus, Seladonia, Asia.
\end{abstract}

\section{Halictus (Seladonia) seladonius (Fabricius)}

(Figs. 10: A-E, 11: A-E, 12: A-H )

Apis seladonius Fabricus, 1794, Ent. syst., 4: 460 [female, Italy, Lectotype: Kopenhagen].

Halictus (Seladonia) seladonius: Ebmer, 1978, Linzer biol. Beitr., 10: 23 [Iran]; Ebmer, 1980, Linzer biol. Beitr., 12: 473 [Afghanistan]; Ebmer, 1988, Senckenbergiana biol., 68: 340-341.

Halictus geminotus Pérez, 1903, Esp. nouv. Mellif.: 42; Proc. Verb. Soc. Linn. Bordeaux, 58: 209, [female \& male, France: Coueron. Lectotype: Paris].

Redescription.

Female. Body $7.50-8.30 \mathrm{~mm}$, fore wing with tegula $4.70-6.00 \mathrm{~mm} \quad(\mathrm{n}=5)$.

Color: Generally clear, golden green reflections, especially on face, mesoscutum,

* Contribution from the Entomological Laboratory, Faculty of Agriculture, Kyushu University, Fukuoka (Ser. 5, No. 63). 
scutellum and metasomal terga; non-metallic parts rather brownish than blackish; mandible with apical half reddened; flagellum beneath brownish black, scape and pedicel blackish; lateral lobe of pronotum yellow apically; tegula yellowish transparent; veins and pterostigma brownish; femora brownish black, tibia and tarsus brown, apices of femora, bases and apices of tibia yellow, tibial spurs yellow; posterior margins of metasomal terga brownish.

Pilocity: Generally yellowish white, $300-350 \mu$ on vertex, $300-330 \mu$ on face, $200-$ $250 \mu$ on gena, $300-330 \mu$ on pronotum, $200-250 \mu$ on mesoscutum centrally, 230 $280 \mu$ on mesoscutellum marginally and sternal hairs $230-280 \mu$; tomental hairs behind lateral lobe of pronotum large and denser; tegula with short brownish yellow hairs anteriorly and posteriorly; basilateral patch on $\mathrm{T} 1$ dense; metasomal terga with broad apical bands of yellowish white hairs, T1 interrupted, T2-4 complete, surface with short yellowish hairs.

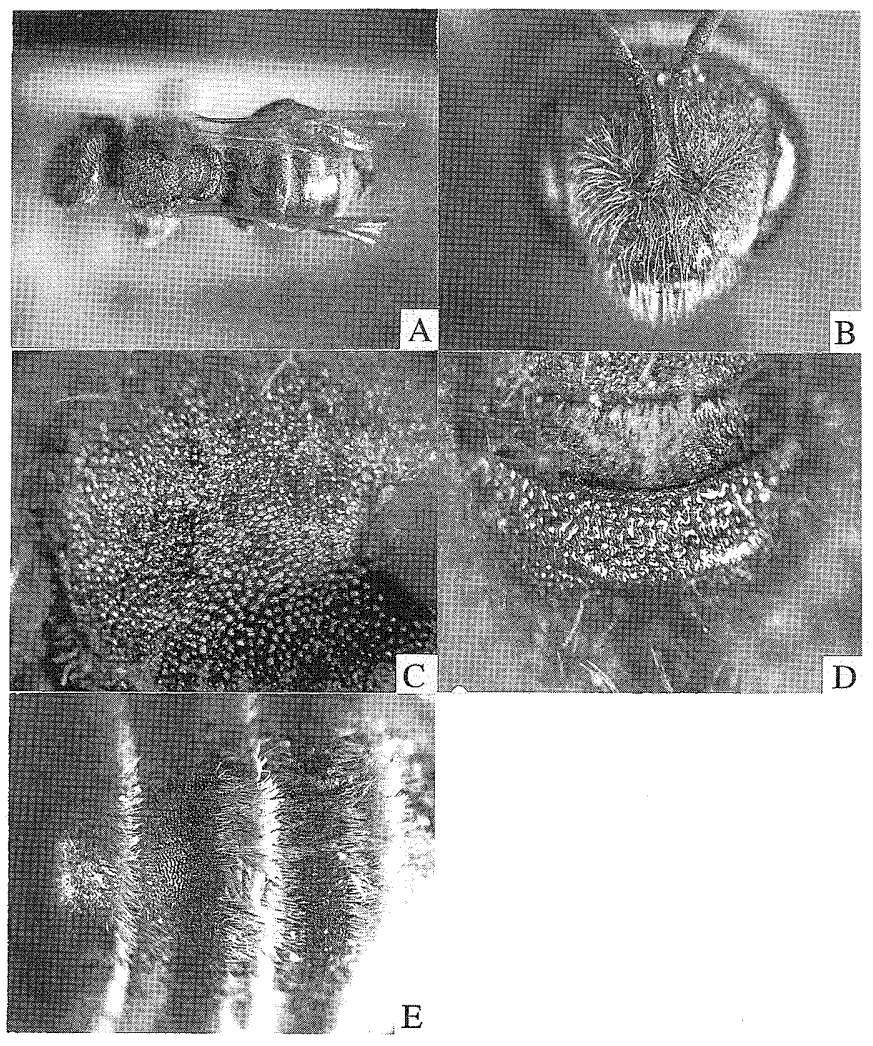

Fig. 10: A - E. Halictus (Seladonia) seladonius (Fabricius), female. A: whole body; $\mathrm{B}$ : head in frontal view; C: mesoscutum; D: propodeum; E: metasomal terga. 
Structure: Head: HW : HL $=2.20: 1.87 ; \mathrm{HW}: \mathrm{MsW}: \mathrm{MtW}=2.20: 2.07: 2.53$. Vertex flat in frontal view, shiny and smooth, more or less roughened with roughened PP. Mean ratio of IOD : OOD : OCD $=0.37: 0.47: 0.25$. Eyes with upper interorbital distance conspicuously wider than lower interorbital distance. MOD : UOD : LOD = $1.53: 1.47: 1.30$. Postocellar PP, $20-25 \mu \varnothing$, rather ill-defined, ocellocular with irregular PP, $20-28 \mu \varnothing$, IS $=0.1-2$, postocellar depression relatively conspicuous. Frons weakly convex; frontal carina short, relatively shorter than carina-ocellus distance. Paraocular area with epistomal angle roundly obtuse, lower margin slightly ascending laterad, PP, $20-25 \mu \phi$, IS $=0.2-1$ above, $25-30 \mu \phi$, IS $=0.2-2$ below. Supraclypeus slightly higher than clypeus, with PP, $25-30 \mu \emptyset$, IS $=0.3-1.5$. Clypeus flat, CPL : CAL : APL $=0.53: 0.93: 0.30$, smooth and shiny with sparse PP, $20-30 \mu \varnothing$, IS $=0.2-2$. Genal area broader than eye, EW : GW $=0.46: 0.53$, surface with small sparse PP, shiny and smooth. Mesosoma: Pronotum without lateral ridges;

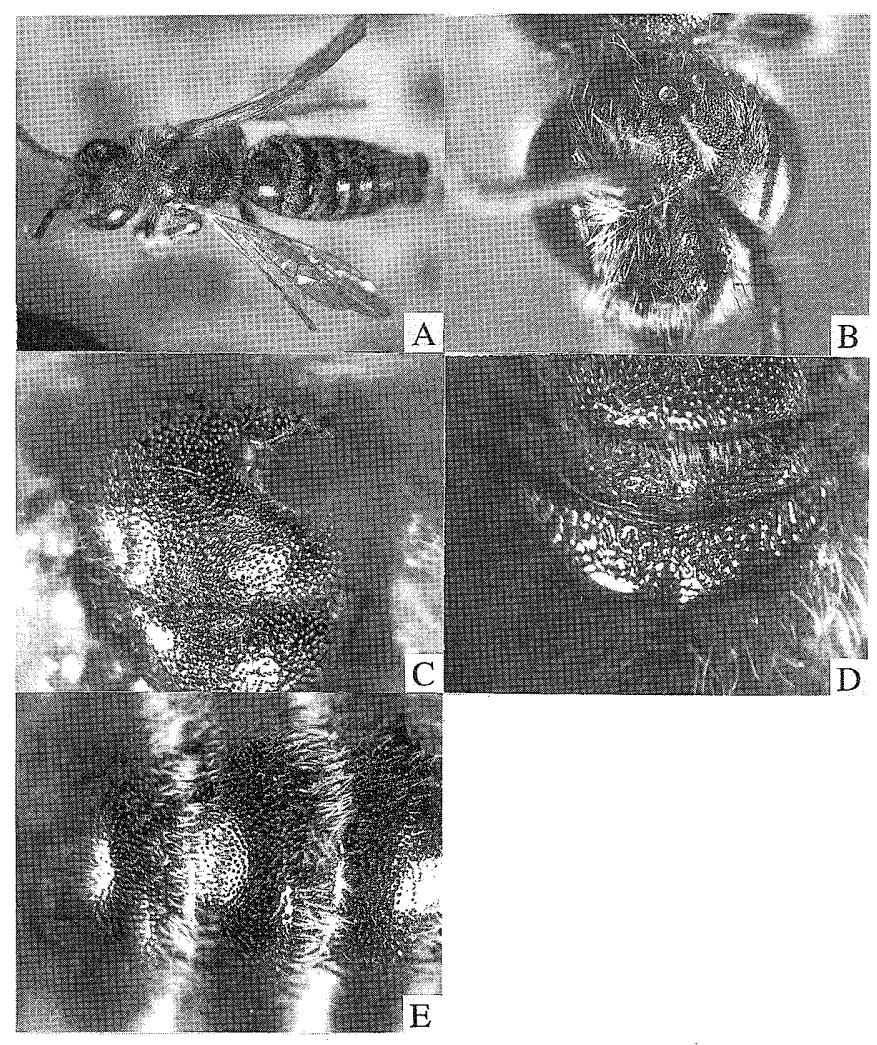

Fig. 11: A - E. Halictus (Seladonia) seladonius (Fabricius), male. A: whole body; B: head in frontal view; $\mathrm{C}$ : mesoscutum; D: propodeum; E: metasomal terga. 
lateral surface shagreened. Mesoscutum weakly shiny with irregular but distinct PP, 25$30 \mu \varnothing$, IS $=0.1-1$, scutellum medially not depressed longitudinally, with denser and smaller PP anteromedially. Scutellum : metanotum : propodeal dorsum $=0.49: 0.29$ : 0.37. Propodeal side homogeneously tessellate with indistinct sparse PP, with IS shagreened; propodeal dorsum with enclosure slightly depressed, ridges relatively less and irregular, occupying basal 4/5 rugosed, and apical 1/5 tessellate, lateral field weakly tessellate and shagreened, propodeal declivity weakly tessellate with sparse PP. Tegula nearly smooth broadly. Inner hind tibial spur with $6-7$ relatively long and round-tipped teeth. Metasoma: T1 smooth and shiny, PP fine, $7-8 \mu \phi$, rarely 12 , IS $=0.1-1$, sparser on apical narrow area, T2, 3 weakly tessellate and a little more roughened with sparser PP, $7-10 \mu \emptyset$, IS $=1-2.5$. Pygidial plate U-shaped. Metasomal sterna with relatively sparse indistinct $P P$.

Male. Body: $7.00-7.30 \mathrm{~mm}$, fore wing with tegula $4.50-4.90 \mathrm{~mm}(\mathrm{n}=2)$.

Color: As in female, non-metallic parts rather brownish than blackish; mandible with apical half reddened; flagellum beneath brownish yellow, scape and pedicel blackish; lower 1/5 of clypeus, basal part of mandible and pronotal lobe apically lemon yellow; tegula brownish yellow semitransparent; apices of femora, tibiae except middle parts and all tarsi lemon yellow; posterior margin of metasomal terga brownish black.

Pilocity: Relatively paler and tomental patch well developed as in female; hairs 230 $280 \mu$ on vertex, $330-390 \mu$ on face, $330-360 \mu$ on pronotum, $170-200 \mu$ on mesoscutum centrally, 250 - 300 $\mu$ on mesoscutellum marginally, and sternal hairs posteriorly $170-200 \mu$; metasomal terga with apical bands of yellowish white hairs, T1 complete, T2-4 narrowly interrupted, surface with very short yellowish hairs.

Structure: Head: HW : HL $=1.73: 1.63 ; \mathrm{HW}: \mathrm{MsW}: \mathrm{MtW}=1.73: 1.67: 1.63$. Vertex round in frontal view, shiny and smooth. Postocellar PP more or less roughened, $10-15 \mu \emptyset$, IS $=0.1-1$, ocellocular PP distinct, $20-28 \mu \emptyset$, IS $=0.2-1.2$. Flagellar segments F1-3 L : F10 L and F2 W $=0.17: 0.23: 0.19: 0.29: 0.21$. Supraclypeus slightly convex, smooth and shiny with PP irregular in size and distribution medially 15 $30 \mu \varnothing$, IS $=0.2-2$. Clypeus flat, upper margin rather horizontal, smooth and shiny with sparse PP, $25-30 \mu \varnothing$, IS $=0.2-1.5, \mathrm{CPL}: \mathrm{CAL}: \mathrm{APL}=0.47: 0.70: 0.33$. Genal area distinctly narrower than eye, EW : GW $=0.47: 0.35$. Mesosoma: Pronotum without lateral ridges, lateral surface finely coriaceous and rather shiny. Mesoscutum smooth and shiny with distinct PP, $15-30 \mu \emptyset$, IS $=0.2-1.5$, scutellum medially not depressed longitudinally, with similar PP. Scutellum :metanotum :propodeal dorsum = $0.35: 0.20: 0.23$. Propodeal side with PP, $15-25 \mu \emptyset$, relatively dense, IS $=0.5-1$, finely reticulate; propodeal enclosure with irregular ridges, not strong, central part anastomosing, latearal part paralleled, lateral field smooth and shiny, with sparse PP; propodeal declivity smooth and shiny with distinct PP. Tegula as in female. Hind tibia : hind basitarsus : hind distitarsus $=1.07: 0.60: 0.83$. Metasoma: T1 smooth and shiny all over with anterior declivity with sparse PP, median with dense PP, $5-15 \mu \emptyset$, IS = 0.2 - 2; T2,3 similar to T1 with PP fine. T7 smooth and shiny with round apex without carination. S7 not elongated with round apex, S8 medially mildly projecting, apex not 

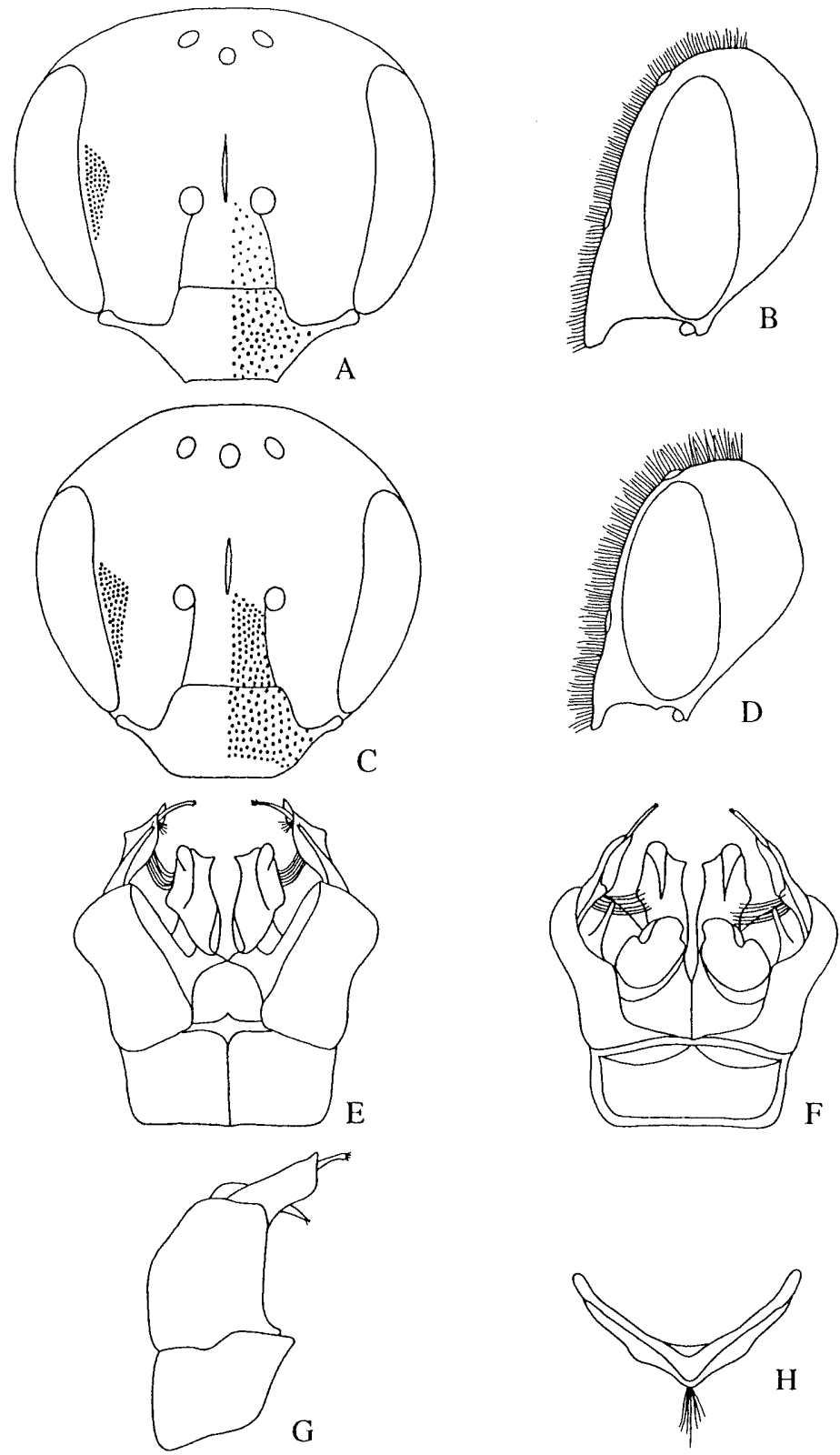

Fig. 12: A - H. Halictus (Seladonia) seladonius (Fabricius). A: frontal view of the head, female; B: lateral view of the head, female; C: frontal view of the head, male; D: lateral view of the head, male; E: dorsal view of the male genitalia; F: ventral view of the male genitalia; G: right lateral view of the genitalia; $\mathrm{H}$ : sterna 7 and 8 of the male. 
sharply pointed. Genitalia: Gonostylus with apex pointed, sublaterally distinctly convex, tufted hairs relatively stout; modified hairs moderate long; dorsal lobe not existed, ventral lobe slender, distinctly shorter than main body.

Specimens examined: IRAN: Elburs: 1 male, Damavand-Gebiet, Polur Umg., 2200 m, 22. vii. 1977 (A. W. Ebmer); 1 male and 1 female, $50 \mathrm{~km} \mathrm{~S}$ (90 km Strabe), Chalus 2800 m, 26. vii. 1977 (A. W. Ebmer).

Remarks: This species is widely distributed from northwest China to Europe and north Africa. It is characteristic in the Asian seladonius species group by having the metasomal terga with dense hairs and broad apical hair bands, the metasomal tergum 1 with dense basilateral patch, the upper interorbital distance conspicuously wider than lower interorbital distance, the pronotum without lateral ridges, the mesoscutum with irregular but distinct dense PP, the propodeal enclosure slightly depressed with ridges occupying

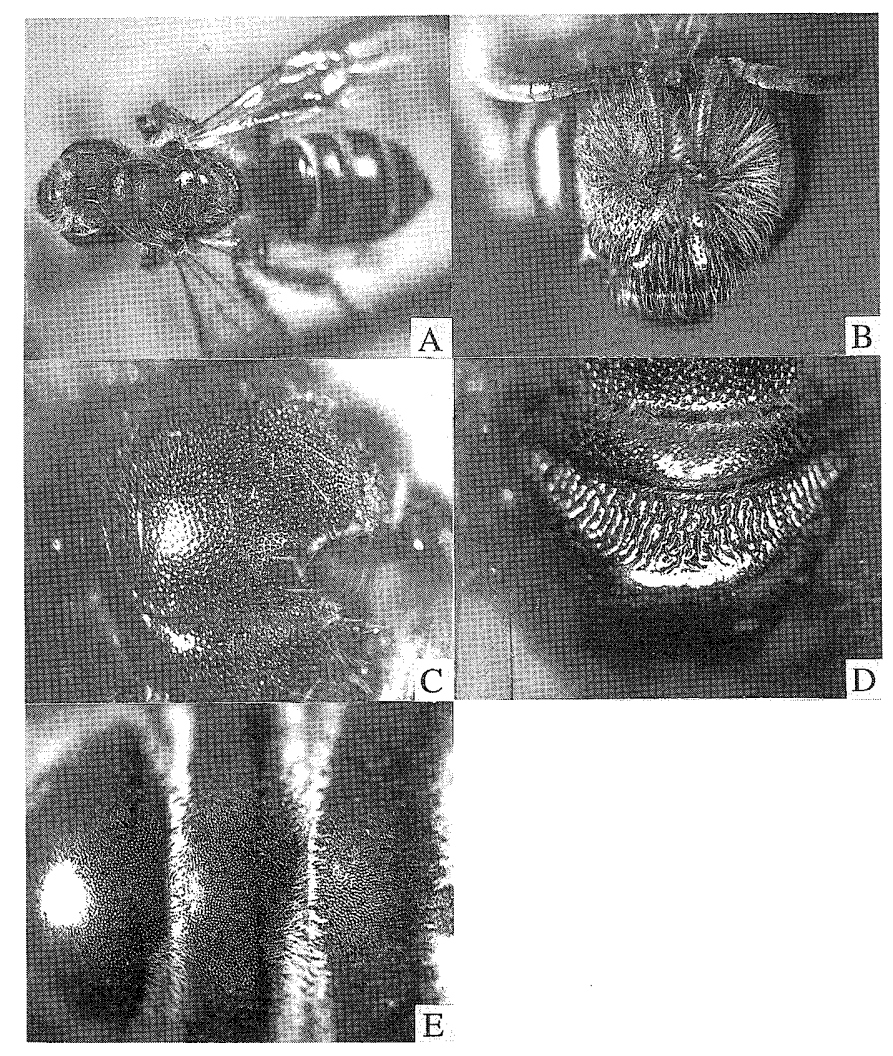

Fig. 13: A - E. Halictus (Seladonia) propinquus Smith, female. A: whole body; B: head in frontal view; C: mesoscutum; D: propodeum; E: metasomal terga. 
basal 4/5 rugosed and apical $1 / 5$ tessellate, inner hind tibial spur with 6-7 teeth and the male clypeus with lower $1 / 10$ yellow.

Distribution: China (Xinjiang), Kyrgyzstan, Tajikistan, Uzbekistan, Afghanistan, Iran, European Russia, Hungary, Romania, Bulgaria, Greece, former Yugoslavia, Austria, Slovakia, Switzerland, Italy, France, Spain, Portugal, N. Africa (Tunis).

Floral association: Not available.

\section{Halictus (Seladonia)propinquus Smith}

(Figs.13: A-E, 14: A-E, 15: A-H)

Halictus propinquus Smith, 1853, Catal. Hym. Brit. Mus., 1: 60-61 [male, N. India]; Ebmer, 1980, Linz. biol. Beitr., 12: 481.

Halictus (Seladonia) propinquus: Sakagami \& Ebmer, 1987, Linzer biol. Beitr., 19: 321,

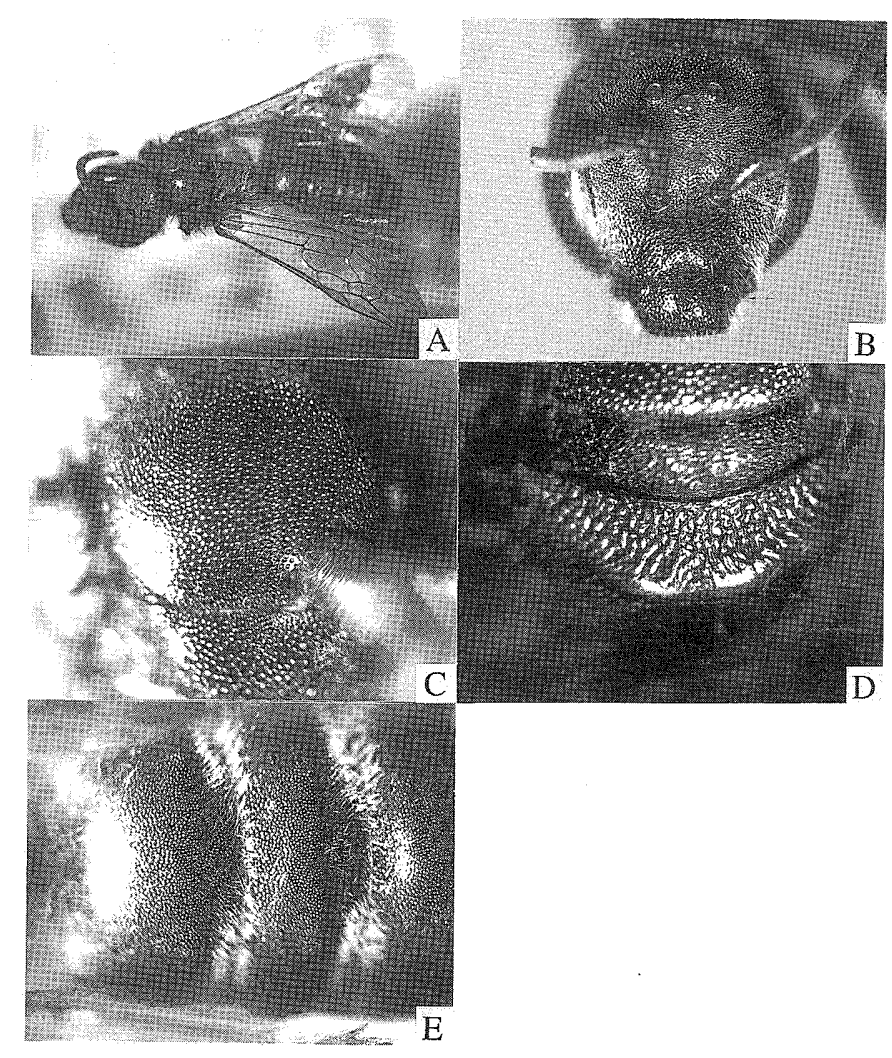

Fig. 14: A - E. Halictus (Seladonia) propinquus Smith, male. A: whole body; B: head in frontal view; C: mesoscutum; D: propodeum; E: metasomal terga. 

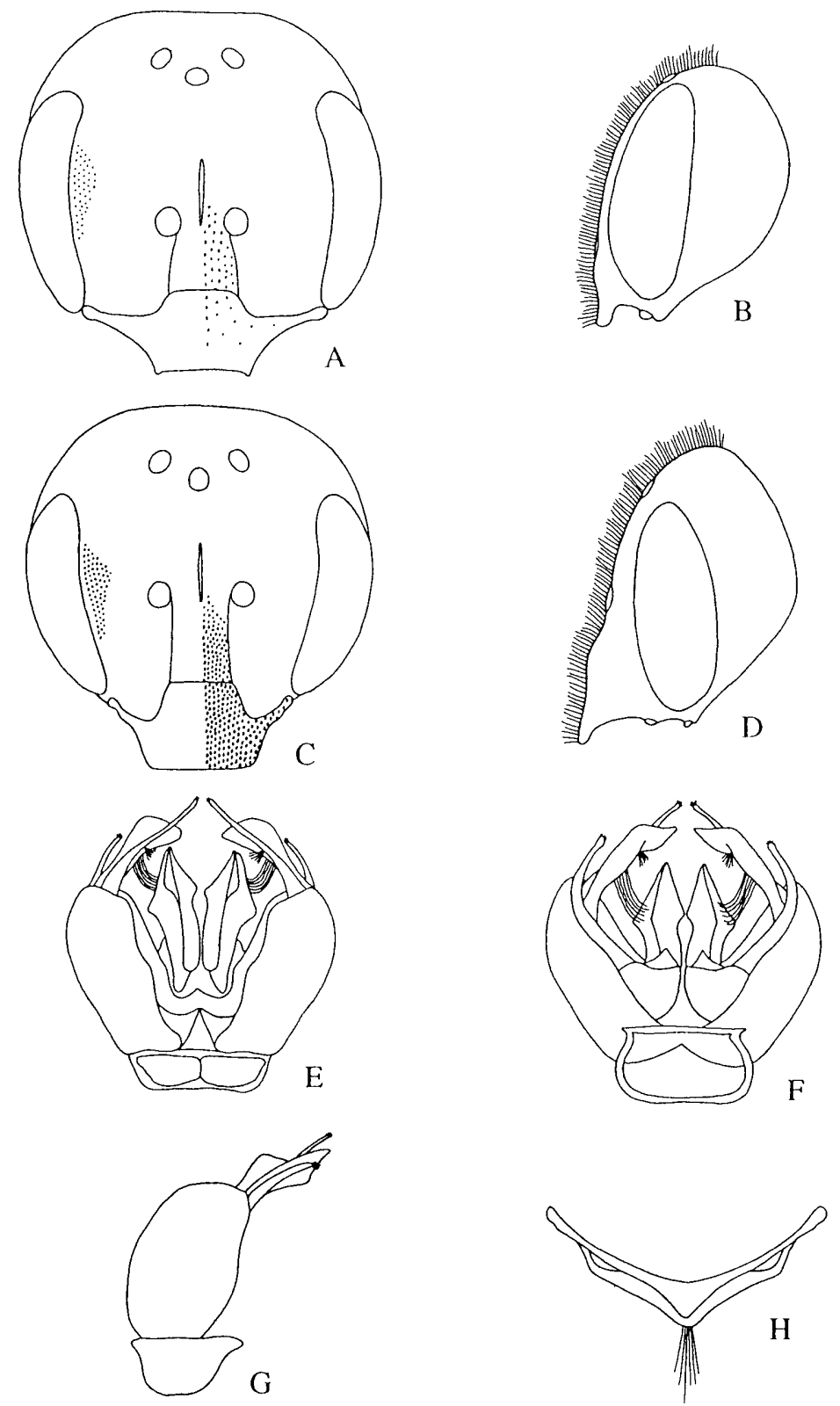

Fig. 15: A - H. Halictus (Seladonia) propinquus Smith. A: frontal view of the head, female; B: lateral view of the head, female; C: frontal view of the head, male; D: lateral view of the head, male; E: dorsal view of the male genitalia; F: ventral view of the male genitalia; G: right lateral view of the genitalia; H: sterna 7 and 8 of the male. 
33374344; Ebmer, 1988, Senchenbergiana biol., 68: 3445.

Hactictus gndindiceps Cameron, 18996, Mem. Prec. Manchester Soc., 41 (4): 98.9-99 [female, N. India: Mussporie].

Hathictus rdiexis Camonon, 18896, Mem. Proc. Mamehester Soc., 41 (44): 9900100 [female, India: Barrackpore].

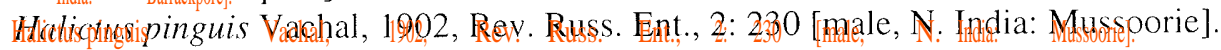

Rederistiption. See Sakagami and Ebpmer (19897).).

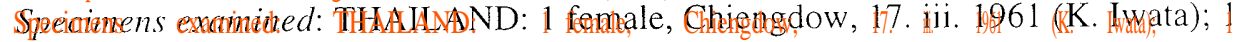
fenale, Fong, 29. xi. 1962 (AA. Nagatomi). NEPAL: 1 male, Kharghok, 299. i. 1966 (T. Kaxwiamichi); 5 fomales, Bhanjang, 3.1. 1. 19268 (T. Kawamichi); 1 female, Betrawati, Ramble 1000 - 15000 m, 17. x. 19974 (I. Kudo); 4 fermales, Kathmandu, 200. ji. 1,968 (TKakrawamichi); 1 male, Kadthmandu, 14. wi. 19868 (T. Matsumura); 1 male, Rurakot Thal, 199. v. 19868 (T. Kumata); Godayari, Napal valley (T. Matsumura): 1 female, 26. jii.

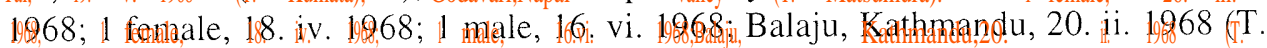
Matsumura); 2 forates, Bajlaju, Kathmandu, 22. iii. 1968 (T. Matsumura); Godavari,

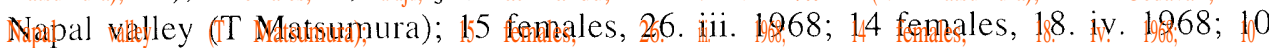
foratales, 199. iv. 19968: 32 females, 20. iv. 10968; 7 females, 22. iv. 18868; 2 females, 25. iv. 19968; 1 fomale, 26. iv. 19868; 1 female, Tatomani, Palpa, 3. v. 1968 (T. Kumata); 1 formale, Pokhare, No. 3 Weast 800 m, 9. iv. 19972 (T. Matsumura); 1 fermale, Bakho-

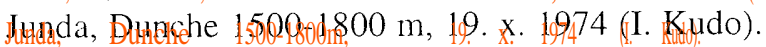

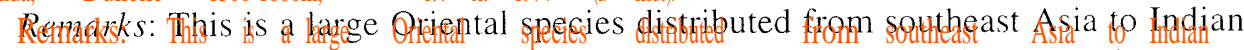

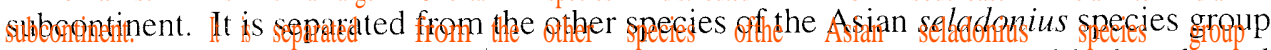

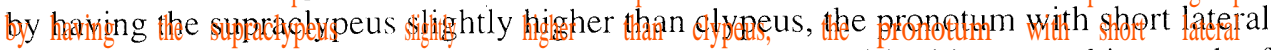
Hidges and the propardeal encolosure mildly depressed with ridges reaching end of encolsure.

Bistibrilor tion: Myanmmar; Andia; Nepal; Thanaland.

Foraral assegetgation: Not avaiblable.

\section{Hallictus (SSeldadonia) sublamuratus (Rossi)}

(Figs. 16: $A E, E, 17: A E E, 18: A-H)$

Apis sublatutata Rossi, 19292, Mant. Ins.: 1444, [female, unknown: Italy: Pisa?]

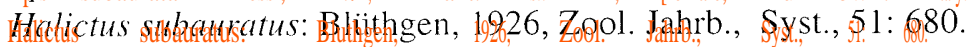

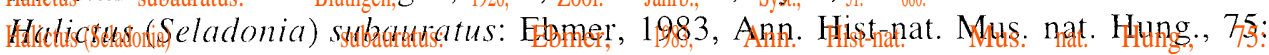
322.

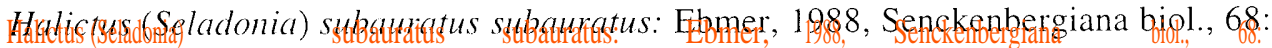
$341-344$.

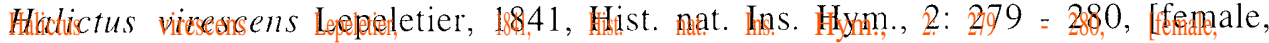
France].

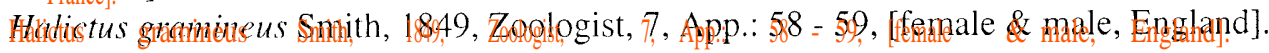


Halictus meridionalis Morawitz, 1873, Hor. Soc. ent. Ross., 10 (1874): 170 - 172, [female \& male, Kaukasus: Derbent].

Halictus subauratus syrius Blüthgen, 1933, Dt. ent. Z., 1933: 72, [female, North

Lebanon: Becharré].

\section{Redescription.}

Female. Body: $7.35-9.60 \mathrm{~mm}$. Fore wing with tegula $4.45-5.80 \mathrm{~mm}(\mathrm{n}=10)$.

Color: Generally clear, rather golden green reflection, especially on face, mesoscutum, scutellum and metasomal terga; non-metallic parts rather blackish to blackish brown than brownish; flagella below blackish brown; lateral lobe of pronotum with apical small part yellow; tegula not transparent, yellowish brown; legs brownish black, apices of femora, bases of tibia and tarsus yellowish brown; posterior margins of metasomal terga yellowish brown.

Pilosity: Relatively deeper-colored, brownish yellow, 280 - 310 $\mu$ on vertex, 260 -

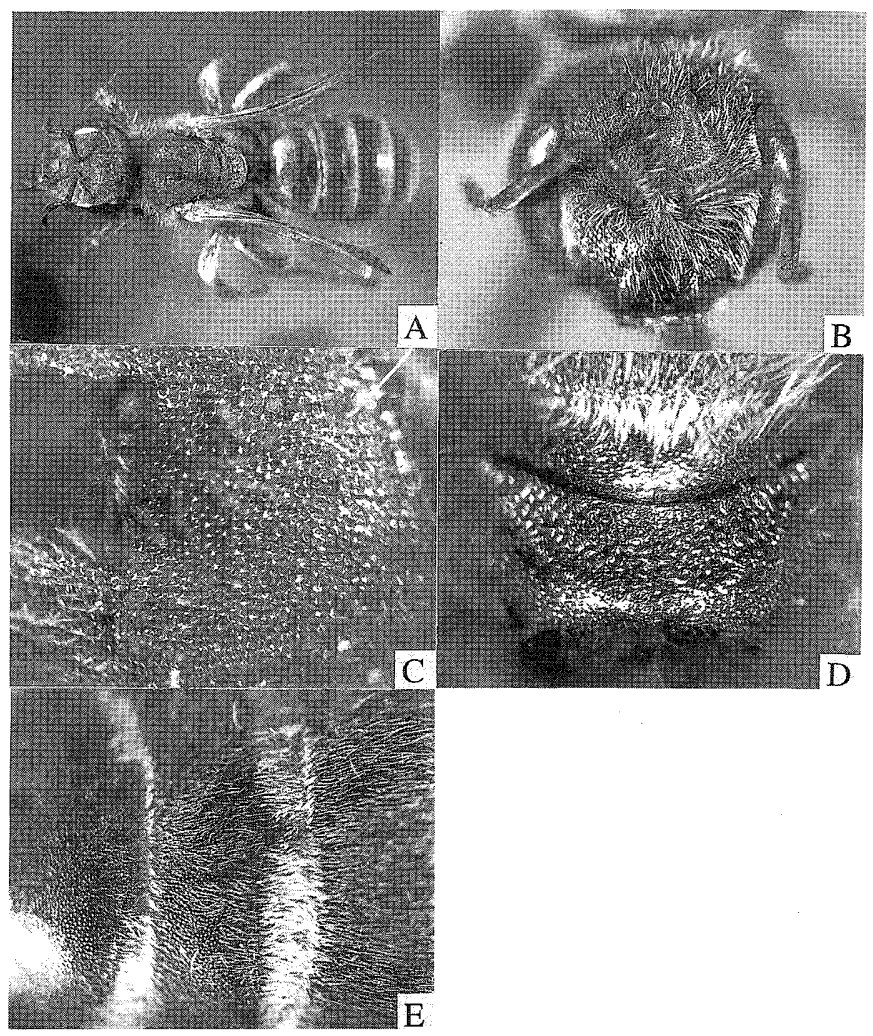

Fig. 16: A - E. Halictus (Seladonia) subauratus (Rossi), female. A: whole body; B: head in frontal view; C: mesoscutum; D: propodeum; E: metasomal terga. 
$280 \mu$ on face, 230 - $260 \mu$ on pronotum, 200 - $230 \mu$ on mesoscutum centrally and 210 $260 \mu$ on mesoscutellum marginally; sternal hairs posteriorly $270-330 \mu$; tomental patch less developed, along inner orbit narrow and covering the surface not dense; tomental hairs of lateral surface of pronotum plenty; tegula with yellowish short hairs anteriorly; basilateral patch on $\mathrm{T} 1$ small to moderate; metasomal terga with broad apical bands of yellowish white hairs, T1 interrupted, T2-4 complete, surface with short yellowish hairs.

Structure: Head: HW : HL = 2.27:2.10; HW : MsW : MtW = $2.27: 2.20: 2.45$. Vertex flat, IOD : OOD : OCD $=0.33: 0.45: 0.30$, both OOD and OCD conspicuously long. MOD : UOD : $\mathrm{LOD}=1.63: 1.47: 1.27$, LOD notably narrower than MOD. Postocellar PP, 25 - 28 $\mu$, rather shiny, ocellocular PP, $25-30 \mu \emptyset$, IS $=0.1-0.2$, postocellar depression relatively conspicuous. Frons slightly convex, frontal carina relatively short, shorter than carina-ocellus distance. Paraocular area with epistomal

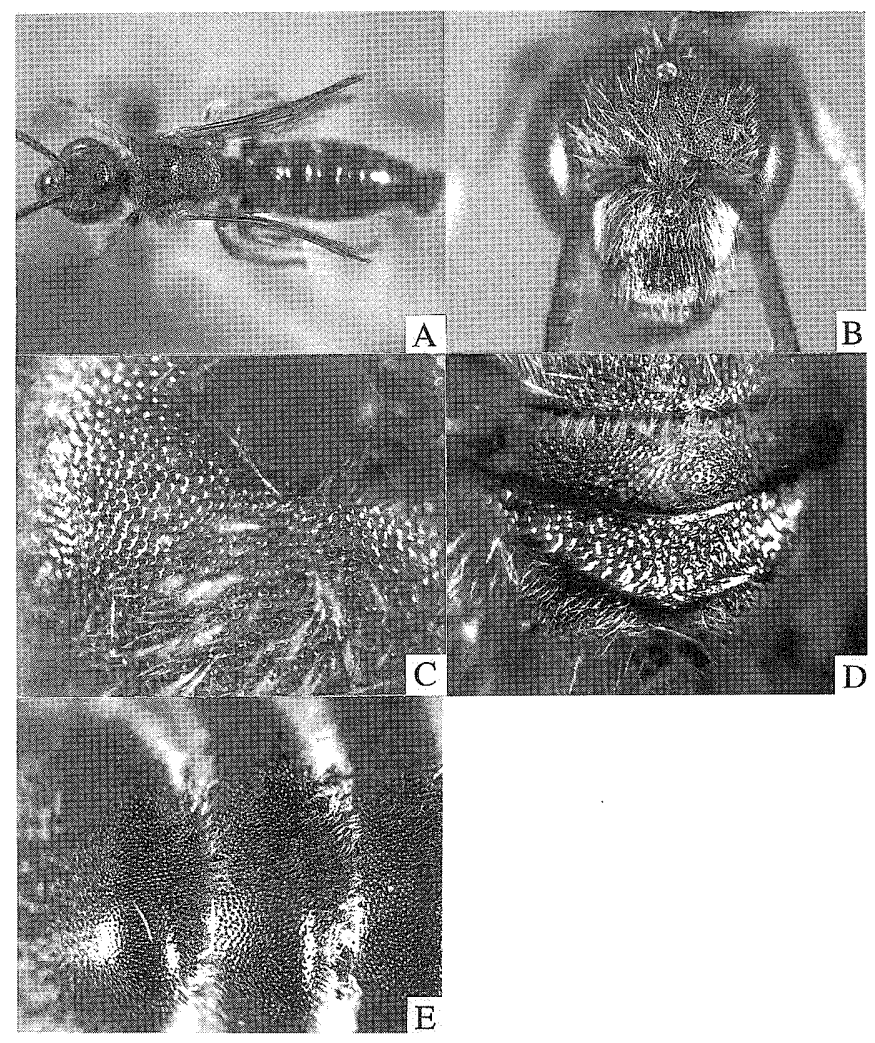

Fig. 17: A - E. Halictus (Seladonia) subauratus (Rossi), male. A: whole body; B: head in frontal view; $\mathrm{C}$ : mesoscutum; D: propodeum; E: metasomal terga. 

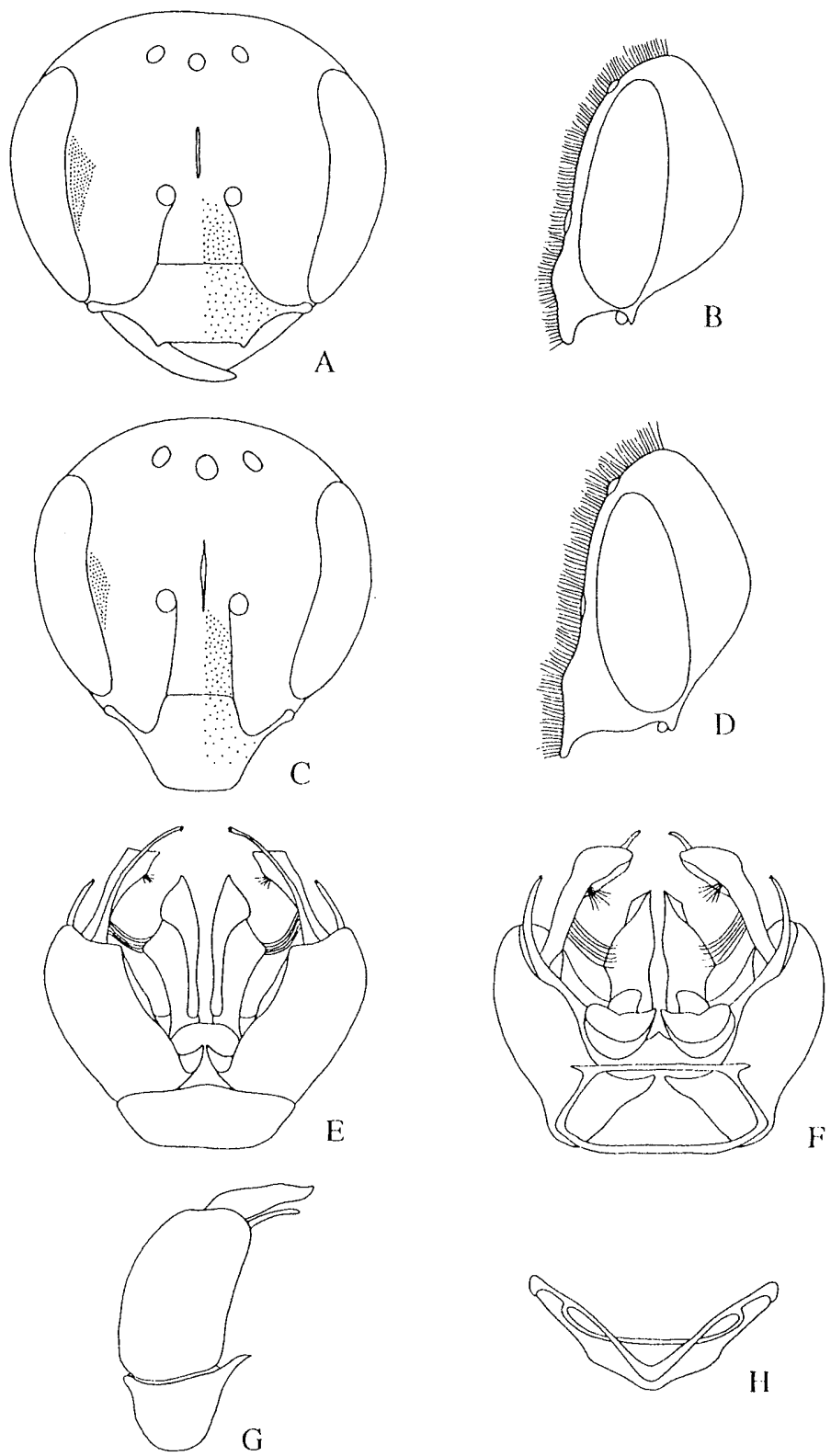

Fig. 18: A - H. Halictus (Seladonia) subauratus (Rossi). A: frontal view of the head, female; B: lateral view of the head, female; C: frontal view of the head, male; D: lateral view of the head, male; E: dorsal view of the male genitalia; F: ventral view of the male genitalia; $\mathrm{G}$ : right lateral view of the genitalia; $\mathrm{H}$ : sterna 7 and 8 of the male. 
angle obtuse, PP $25-28 \mu \varnothing$ above, $25-30 \mu \varnothing$ or more below. Supraclypeus slightly higher than clypeus, with PP, $6-25 \mu \emptyset$, IS $=0.3-2$ or less. Clypeus apically gradually reduced, $\mathrm{CPL}: \mathrm{CAL}: \mathrm{APL}=0.46: 0.70: 0.30$, PP $25-33 \mu \varnothing, \mathrm{IS}=0.3-2.5$ basally, sparser below. Gena conspicuously broader than eye, EW : GW $=0.53: 0.73$ on average. Mesosoma: Pronotum without lateral ridges, lateral surface shining. PP on mesoscutum and scutellum irregular, $15-25 \mu \phi$, rarely $30 \mu \emptyset$, IS variable, $0.1-0.2$ sometimes 0.5 , on scutum and sometimes 1.0. Scutellum medially not depressed longitudinally, propodeal side with sparse but coarse and dinsinct PP. Mesoscutellum : metanotum : propodeal dorsum $=0.41: 0.33: 0.34$. Propodeal dorsum with enclosure mildly depressed, rugosed all over, PP of propodeal declivity above coarser and denser. Tegula nearly smooth broadly. Inner hind tibial spur with 5 - 6 relatively long teeth. Metasoma: T1 smooth and shiny with small, dense PP basally, $8-10 \mu \emptyset$, denser and uniform, IS $=0.2-1$, sometimes 3 on apical narrow area, T2, 3 weakly tessellate and a little more roughened with rather denser PP, $\mu \varnothing 8$, IS $=0.3-1.5$. Pygidial plate Ushaped. Metasomal sterna weakly tessellate with small indistinct PP.

Male. Body: $7.30-9.60 \mathrm{~mm}$, fore wing with tegula $4.50-5.70 \mathrm{~mm}(\mathrm{n}=10)$.

Color: As in female, non-metallic parts rather brownish than blackish; mandible with apical part reddened; flagellum beneath brownish yellow, scape and pedicel blackish; lower 1/4 of clypeus, labrum, median part of mandible and basal parts and pronotal lobe apically lemon yellow; tegula brownish semitransparent; legs brownish black, apices of femora, tibiae except middle parts and all tarsi lemon yellow; terga weakly reddened.

Pilocity: Generally paler and tomental patch well developed as in female; hairs 200 $250 \mu$ on vertex, $300-330 \mu$ on face, $230-280 \mu$ on pronotum, $230-260 \mu$ on mesoscutum centrally, $300-330 \mu$ on mesoscutellum marginally, and sternal hairs posteriorly $100-130 \mu$; metasomal terga with apical bands of yellowish white hairs, T1 narrowly interrupted, T2 - 4 complete, surface with very short yellowish hairs.

Structure: Head: HW : HL $=1.93: 2.1 ; \mathrm{HW}: \mathrm{MsW}: \mathrm{MtW}=1.93: 1.47: 1.87$. Vertex round in frontal view, shiny and smooth, postocellar PP more or less roughened, $15-20 \mu \varnothing$, IS $=0.1-1$, ocellocular PP distinct, $25-30 \mu \varnothing$ IS $=0.2-0.3$, rarely 1 . Flagellar segments F1-3 L : F10 L and F2 W $=0.13: 0.27: 0.23: 0.21: 0.19$. Supraclypeus mildly convex, smooth and shiny with PP, $15-30 \mu \emptyset$, IS $=0.2-1.5$. Clypeus nearly flat, upper margin rather horizontal, smooth and shiny with sparse PP, $10-30 \mu \varnothing$, IS $=1-3$, CPL : CAL : APL $=0.46: 1.04: 0.39$. Genal area broader than eye, $\mathrm{EW}: \mathrm{GW}=0.57: 0.51$. Mesosoma: Pronotum without lateral ridges. Mesoscutum smooth and shiny with dense PP, $15-25 \mu \varnothing$, IS $=0.2-0.3$, scutellum medially not depressed longitudinally, with similar PP. Scutellum : metanotum : propodeal dorsum = $0.47: 0.25: 0.29$. Propodeal side with PP, $10-20 \mu \varnothing$, relatively sparse, IS $=0.3-2$; propodeal enclosure with ridges rather irregular; lateral field nearly smooth and shiny, broadly impunctate above; propodeal declivity smooth and shiny with distinct and sparse PP. Tegula as in female. Hind tibia : hind basitarsus : hind distitarsus $=1.03: 0.53$ : 0.70. Metasoma: T1 smooth and shiny all over; anterior declivity with very sparse PP, disc with dense PP, $8-15 \mu \varnothing$, IS $=0.1-1.5$. T2,3 similar to T1 with PP a little 
roughened. T7 smooth and shiny with round apex without carination. S7 not elongated with round apex, S8 medially mildly projecting, apex not sharply pointed. Genitalia: Gonostylus with apex pointed, sublaterally gently convex, tufted hairs relatively stout; modified hairs moderate long; dorsal lobe slender, ventral lobe distinctly shorter than main body.

Specimens examined: IRAN: 1 female, Karadj, 1500 m, 29. v. 1976 (RessI / Holzschuh); TURKEY: 1 female, URFA, 1. vi. 1968 (J. Gusenleitner); 1 female, URFA As. Turk,21. v. - 28. v. 1972 (K. Kusdas). RUSSIA: 1 male, Kaukasus, Tiflis, Burgberg, 25. vii. 1972 (H. Dathe). FRANCE: Les Eyzies, Dordogne (Quenu): 2 males, 1. x. 1953; 1 male, 6. x. 1953; 1 female, 31. v. 1954; 1 female, 6. vii. 1956; 1 male, 16. vii. 1957; 1 female, 14. viii. 1958; 1 female, 7. ix. 1960; 1 female,Wilhering, Newdecker, Steppenreliht, 5. viii. 1965 (A. W. Ebmer); 1 female, Muhlbach, Hachl, Berg, 22. ix. 1965 (A. W. Ebmer). JUGOSLAVIA: 3 females, Bosnien, Trebinje 300

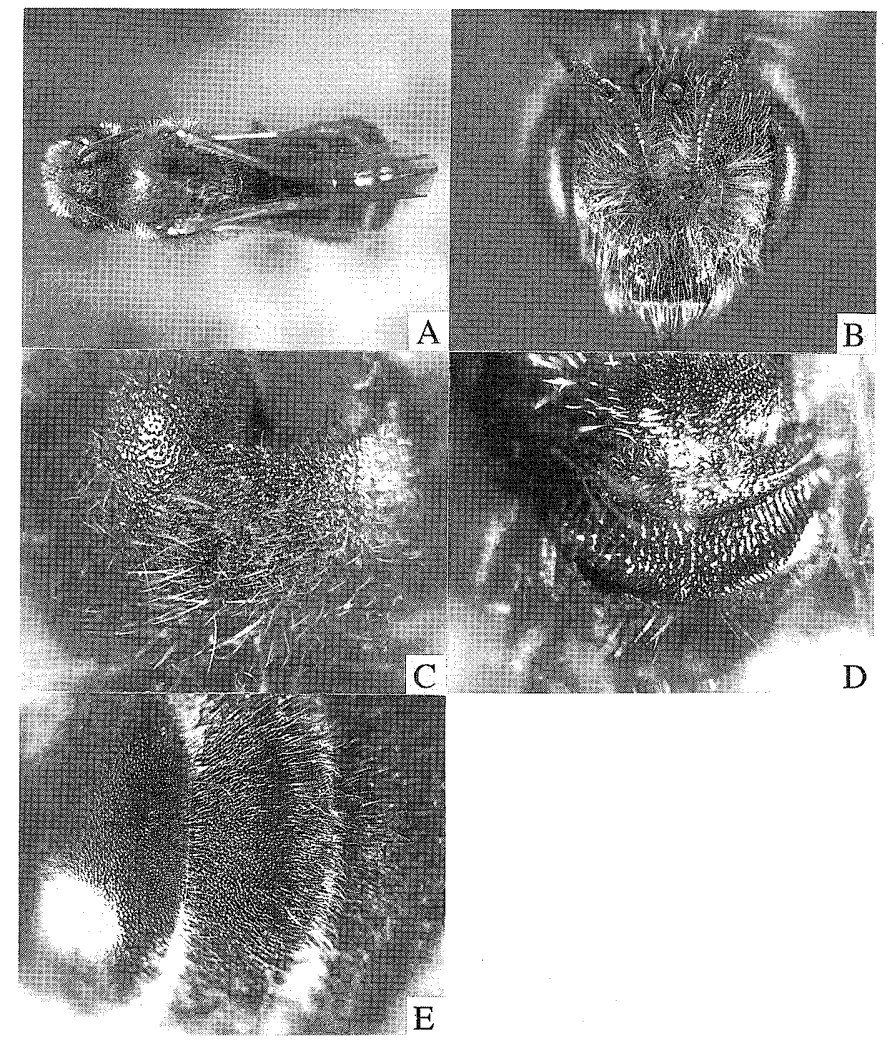

Fig. 19: A - E. Halictus (Seladonia) subauratoides Blüthgen, female. A: whole body; B: head in frontal view; C: mesoscutum; D: propodeum; E: metasomal terga. 
m, 24. vii. 1968 (A. W. Ebmer). BURGARIA: 1 male and 3 females, Newsiedl am See, 11. viii. 1967 (A. W. Ebmer). SWITZERLAND: 2 males and 1 female, Gordola $300 \mathrm{~m}$, 3. viii. 1967 (A. W. Ebmer); AUSTRIA: Oberost., St. Willibald (A. W. Ebmer): 1 male, 30. viii. 1965; 1 male, 31. viii. 1965; 1 female, Oberost., R. Henegg, 22. vii. 1965 (A. W. Ebmer); 1 female, Oberost., Urfahr, Urfahrwand, 19. vii. 1965 (A. W. Ebmer); 1 male, Dorubach, Quterweg, Zum, Steinbruch, 22. ix. 1965 (A. W. Ebmer); 1 male, Alharting, Sandorube, Ost., 27. ix. 1965 (A. W. Ebmer); 1 male, Linz, O. O., 5. ix. 1928 (K. Priesner).

Remarks: This species is widely distributed from central Asia to Europe. It is more or less $H$. seladonius in the Asian seladonius species group by having the metasomal terga hairy with broad apical hair bands, the metasomal tergum 1 with dense basilateral patch and the pronotum without lateral ridges. But it is recognised by the haed less broader than long, the genal area conspicuously broader than eye and the propodeal enclosure

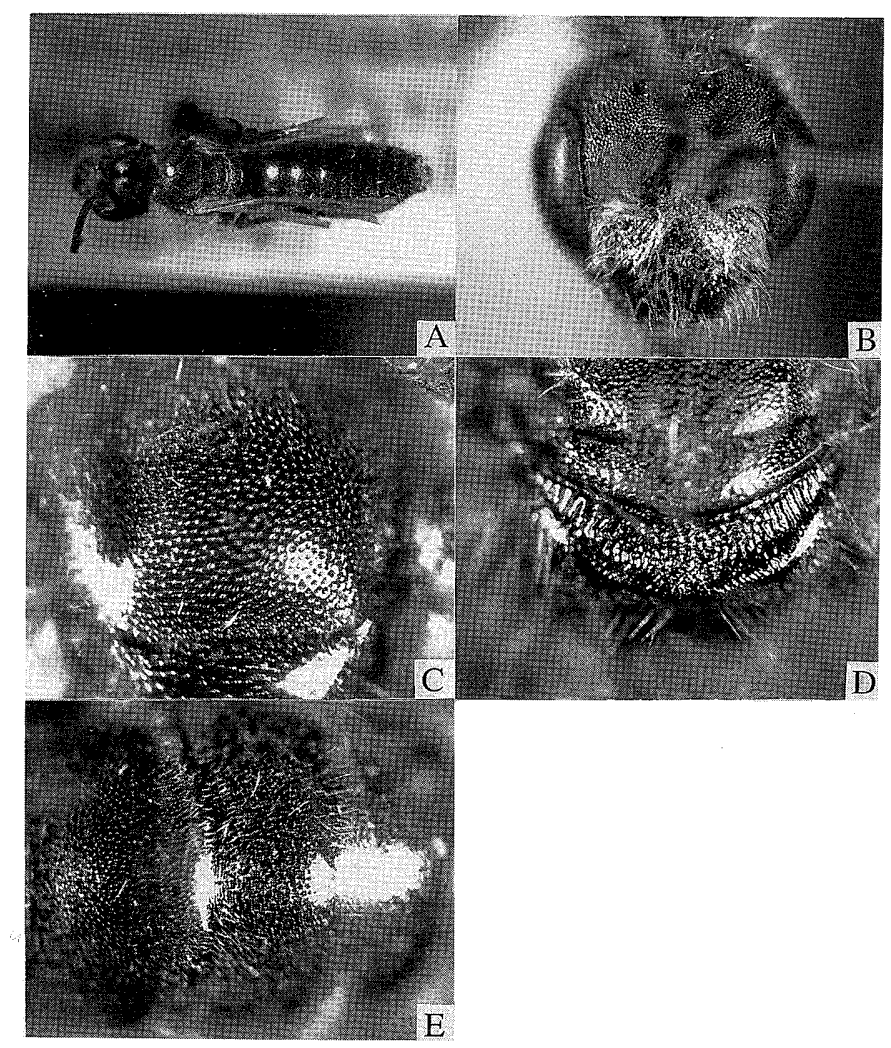

Fig. 20: A - E. Halictus (Seladonia) subauratoides Blüthgen, male. A: whole body; $\mathrm{B}$ : head in frontal view; C: mesoscutum; D: propodeum; E: metasomal terga. 

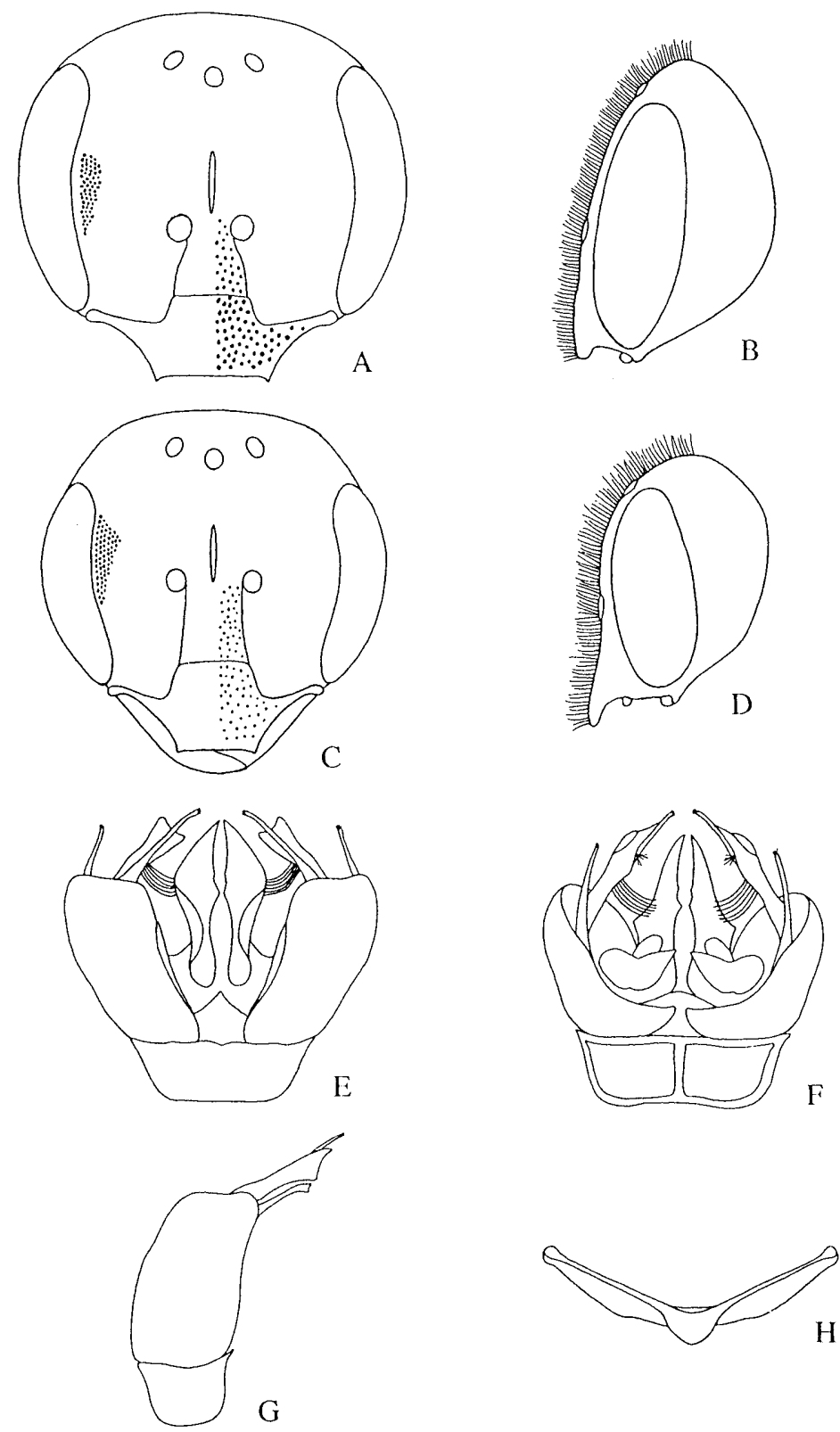

Fig. 21: A - H. Halictus (Seladonia) subauratoides Blüthgen. A: frontal view of the head, female; B: lateral view of the head, female; C: frontal view of the head, male; D: lateral view of the head, male; E: dorsal view of the male genitalia; F: ventral view of the male genitalia; G: right lateral view of the genitalia; H: sterna 7 and 8 of the male. 
rugosed all over.

Distribution: India (Kashmir); old Trukestan; Russia (Siberia: Barnaul); Iran; Turkey; European Russia; Bulgaria, Romania, Poland; Greece; Austria; Czech; Germany, Switzerland; Belgium; France, Italy; Spain; Portugal; England; Morocco.

Floral association: Not available.

\section{Halictus (Seladonia) subauratoides Blüthgen}

(Figs. 19: A-E, 20: A-E, 21: A-H)

Halictus subauratoides Blüthgen, 1926, Zool. Jahrb., Syst., 51: 680, [female, India: Shillong]

Halictus (Seladonia) subauratoides: Sakagami \& Ebmer, 1987, Linzer biol. Beitr., 19: 349-351.

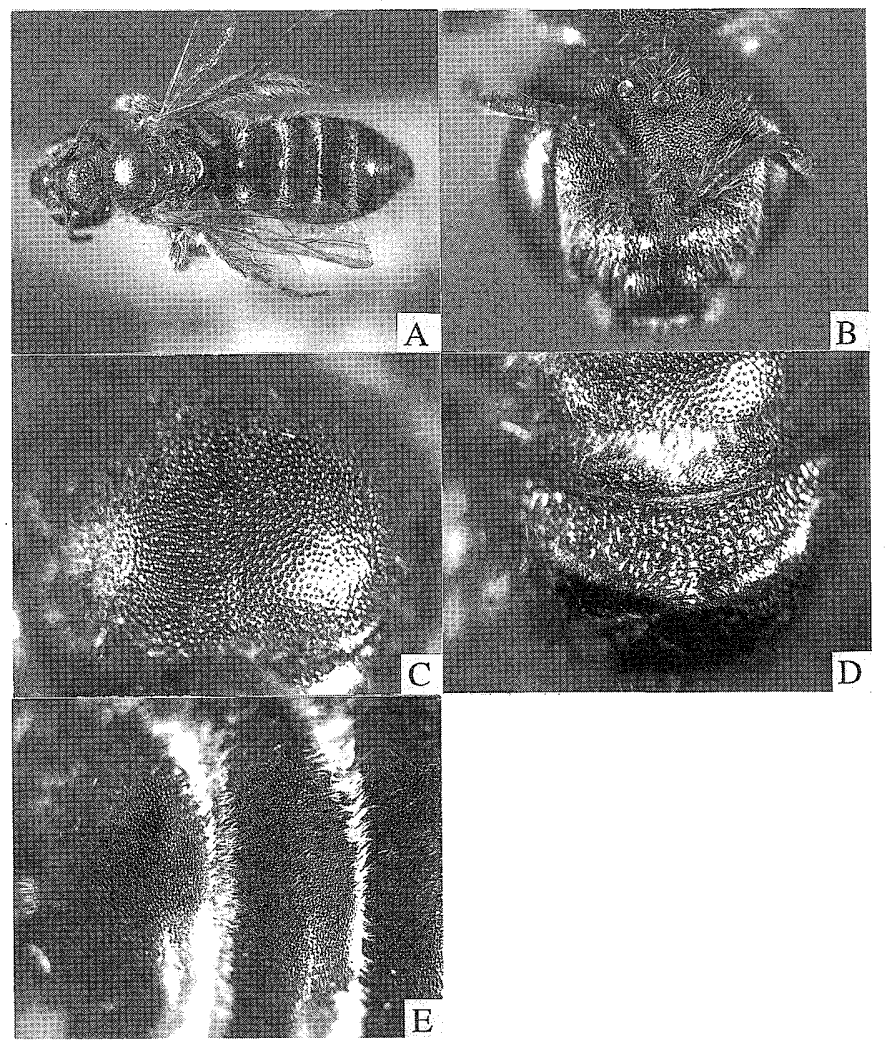

Fig. 22: A - E. Halictus (Seladonia) vicinus Vachal, female. A: whole body; B: head in frontal view; C: mesoscutum; D: propodeum; E: metasomal terga. 
Redescription. See Sakagami \& Ebmer (1987).

Specimens examined: NEPAL: 1 female, Ramche, Bokhajunda 1500-1800, 18. x. 1974 (I. Kudo); 1 female, (I. Yoneta); 2 females, Godavari, Napal valley, 26. iii. 1968; 2 females, Lete, Palpa, 5. v. 1968. INDIA: Uttar, Pradesh, Mussoorie, Lal, Tibba, Alt., 7500 (S. W. T. Batra): 1 male, 14. vii. 1965; 1 male, 21. vii. 1965.

Remarks: This species is an Oriental species occuring in Indian subcontinent. It is recognized by the other species of the Asian seladonius species group by the hairs on the head and thorax very long and erect, the metasomal tergum 1 with basilateral patch sparse, incomplete, the supraclypeus nearly as high as the clypeus, the pronotum with lateral ridges acute and extending below and the propodeal enclosure depressed medially and apical area conspicuously raised with ridges paralleled and strong.

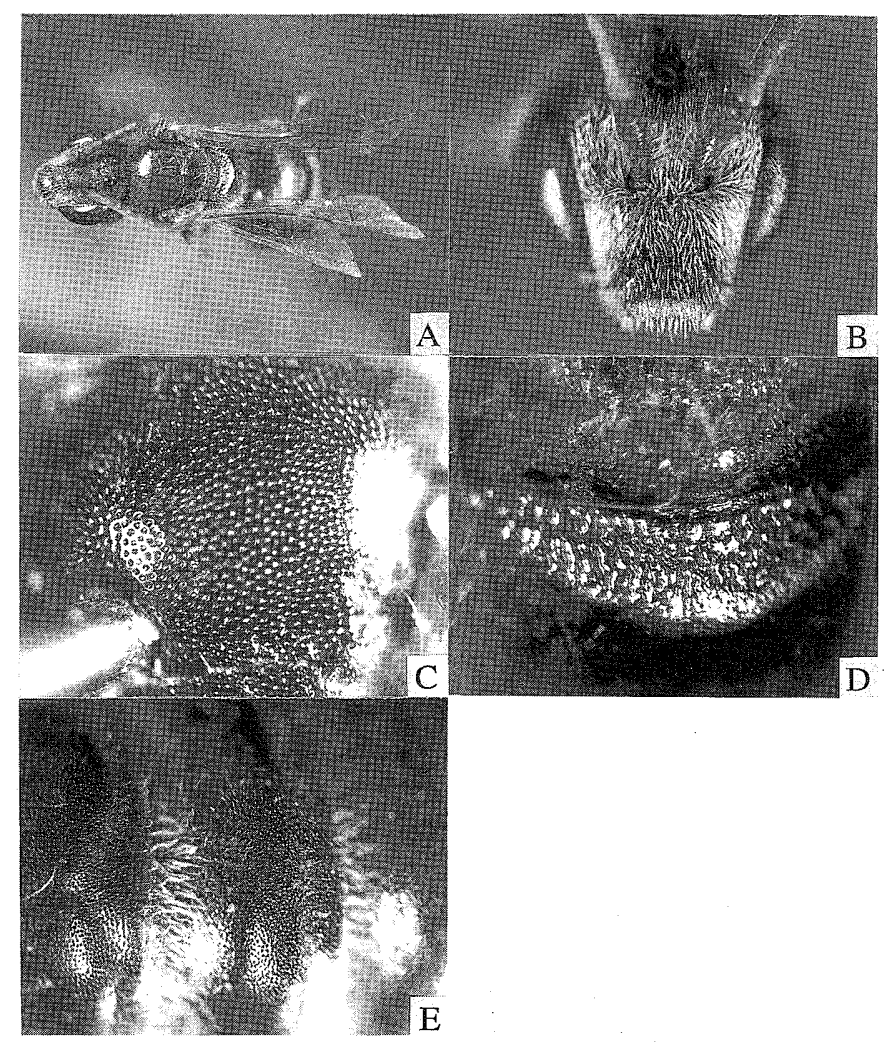

Fig. 23: A - E. Halictus (Seladonia) vicinus Vachal, male. A: whole body; B: head in frontal view; C: mesoscutum; D: propodeum; E: metasomal terga. 

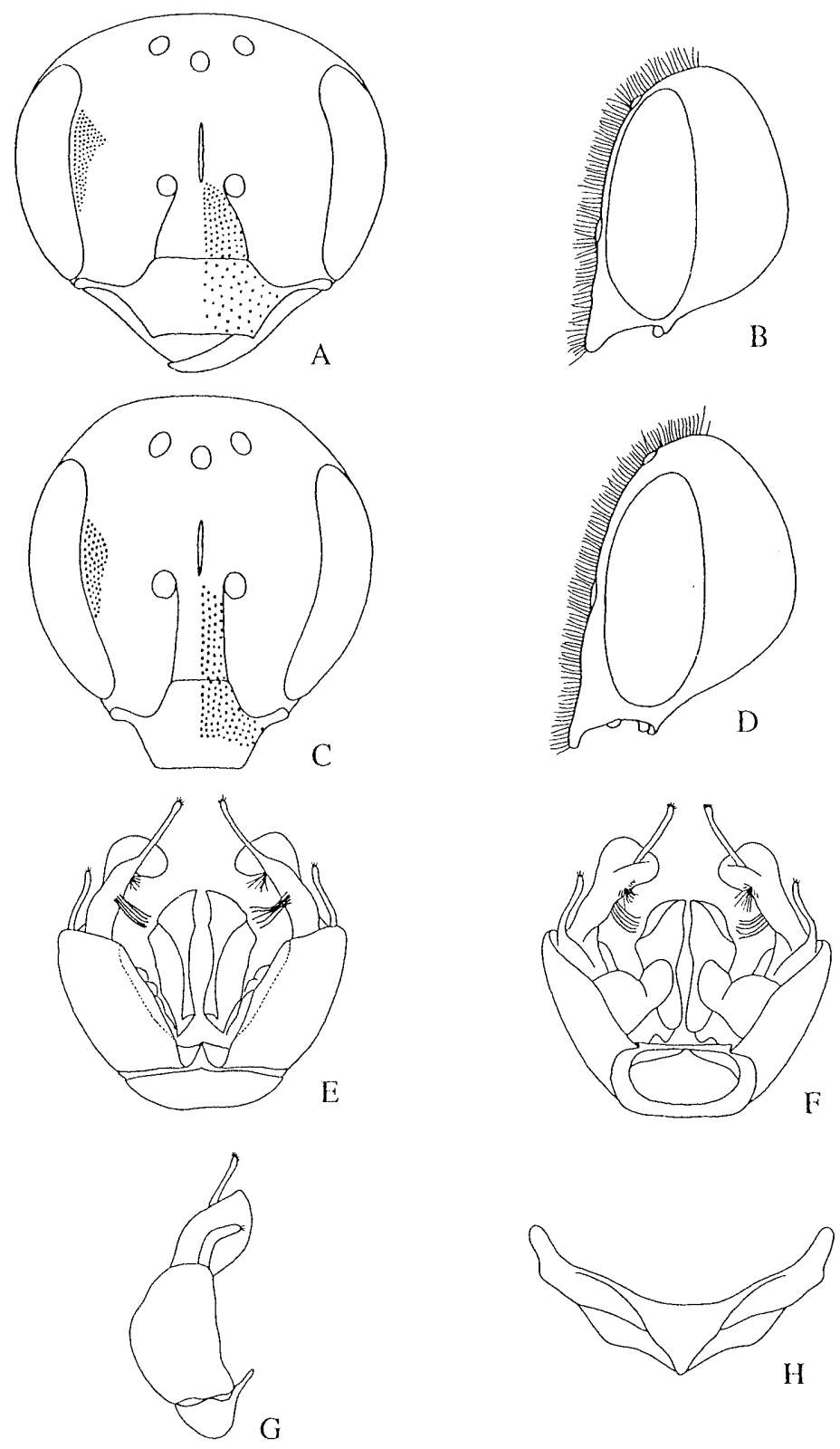

Fig. 24: A - H. Halictus (Seladonia) vicinus Vachal. A: frontal view of the head, female; B: lateral view of the head, female; C: frontal view of the head, male; D: lateral view of the head, male; $\mathrm{E}$ : dorsal view of the male genitalia; $\mathrm{F}$ : ventral view of the male genitalia; G: right lateral view of the genitalia; H: sterna 7 and 8 of the male. 
Distribution: Nepal; India.

Floral association: Not available.

\section{Halictus (Seladonia) vicinus Vachal}

(Figs. 22: A-E, 23: A-E, 24: A-H)

Halictus vicinus Vachal, 1894, Ann. Mus. civ. Stor. nat. Genova, 24: 43 1-432 [female, Burma: Bhamo].

Halictus (Seladonia) vicinus: Sakagami \& Ebmer, 1987, Linzer biol. Beitr., 19: $345-$ 349.

Halictus abuensis Cameron, 1908, J. Bombay nat. Hist. Soc., 18 (2): 310-311 [female, India: Abu].

Halictus propinquus var. silvatica Blüthgen, 1926, Zool. Jb. Syst., 51 : 677 [female, India: Tenasserim - Thandanny].

Halictus daturae Cockerell, 1929, Ann. Mag. nat. Hist., (10) 4: 584-585 [female, Siam: Nan].

Halictus daturae var. laosina Cockerell, 1929, Ann. Mag. nat. Hist., (10) 4: 585 [female, Siam: Nan]

Halictus speculiferus Cockerell, 1929, Ann. Mag. nat. Hist., (10) 4: 585 [female, Siam: Nan].

Halictus umbrosus Cockerell;, 1929, Ann. Mag. nat. Hist., (10) 4: $588-589$ [female, Siam: Nan].

Redescription. See Sakagami \& Ebmer (1987).

Specimens examined: INDIA: Lonavla, W. Ghats (Wain): 1 female, 23. xi. 1959; 1 female, 26. ii. 1961; 1 female, 2. v. 1963; 1 female, 11. v. 1963; 2 females, 13. v. 1963; 1 female, 23. v. 1963; Sinhagad, W. Ghats (Wain): 1 female, 21. v. 1963; 2 males, 25. i. 1964; 1 female, 8. xi. 1964. THAILAND: 1 female, Chiengmai, 1. v. 1961 (K. Iwata); 1 female, Doi Suthep, 18. xi. 1962 (A. Nagatomi); 1 female, Sampatong, 11. xii. 1962 (A. Nagatomi); 1 female, Vbol, 20. xii. 1962 (A. Nagatomi).

Remarks: This species is an Oriental species distributed in southeast Asia and Indian subcontinent. It is recognised by the metasomal tergum 1 with basilateral patch small, the supraclypeus slightly higher than clypeus, the pronotum with lateral ridges mild and short and the propodeal enclosure slightly depressed with ridges irregular, occupying all over.

Distribution: Myanmar; India; Thailand.

Floral association: Not available. 